\title{
Inhibition in ADHD and non-ADHD children ages 6-12 years
}

Rahmi, Iftita $\measuredangle$

Universitas Gadjah Mada, Yogyakarta, Indonesia (iftita.rahmi@mail.ugm.ac.id)

Wimbarti, Supra

Universitas Gadjah Mada, Yogyakarta, Indonesia (supra@ugm.ac.id)

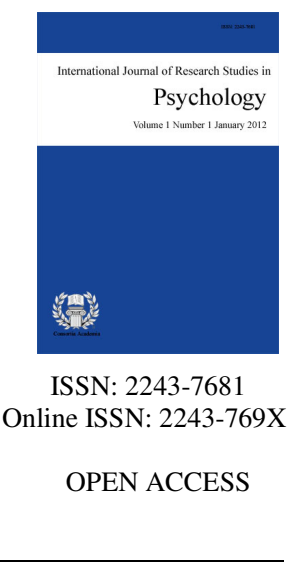

Received: 5 December 2017

\begin{abstract}
Attention-Deficit/Hyperactivity Disorder (ADHD) is a neurodevelopmental disorder that begins to emerge in childhood. This disorder is caused by an impaired prefrontal cortex (PFC) development that affects executive functions, particularly in inhibition, resulting in loss of cognitive and behavior control. This research aims to investigate the difference between inhibition in ADHD and non-ADHD children ages 6-12 years old and between the three subtypes of ADHD. Subjects in this study were children with ADHD (N=34) which consists of the inattentive type $(\mathrm{N}=14)$, hyperactive-impulsive type $(\mathrm{N}=9)$, and combination type $(\mathrm{N}=11)$, as well as non-ADHD children $(\mathrm{N}=34)$. This research used the causal-comparative method. The instrument which was utilized in this study is The Stroop Color and Word test to measure inhibition. Results of this research showed that there are differences in inhibition between ADHD and non-ADHD children and between age 6-9 years and 10-12 years old children. However, there is no difference of inhibition between three subtypes of ADHD.
\end{abstract}

Keywords: age range; Stroop Test; executive function 


\section{Inhibition in ADHD and non-ADHD children ages 6-12 years}

\section{Introduction}

Attention-Deficit/Hyperactivity Disorder (ADHD) is a common behavioral disorder in school-aged children and is a major problem in children and adolescents today (Guldberg-Kjär \& Johansson, 2015; Saputro, 2004). ADHD is a pattern of inattention, hyperactivity, and impulsivity that persists and disrupts one's developmental function (American Psychiatric Association [APA], 2013). In a survey conducted by the National Institute of Mental Health (NIMH) on children in America, ADHD ranks first in the list of mental disorders experienced by children in America that is as much as $8.6 \%$ of the population (NIMH, 2009). Roberts, Milich, and Barkley (2014) concluded that the prevalence of ADHD is currently around 5-7\%. Meanwhile, according to APA (2013) prevalence of ADHD in children today is $5 \%$ and $2.5 \%$ in adults.

In Indonesia alone, an ADHD study conducted by Saputro (2004) found that the prevalence of ADHD in school-age children in the city of Jakarta was $26.2 \%$. A study carried out in Yogyakarta found that the prevalence of ADHD in elementary school students in Yogyakarta was 5.47\% (Hayati, 2014), in Cangkringan District, Sleman 7.48\% (Christina, 2012), and in Banguntapan, Bantul 3.5\% (Dewi, 2011). In a recent study, it was found that the prevalence of ADHD children in Yogyakarta and Sleman is about 8.09\% (Wimbarti, Dewi, \& Khoirot, 2016). In conclusion, based on the above descriptions, the prevalence of ADHD in children is about 3 to $26.2 \%$. The comparison of the number of ADHD cases in boys and girls is 2: 1, and 1.6: 1 in adults (APA, 2013; Roberts et al., 2014). Barbaresi, Weaver, Voigt, Killian, and Katusic (2015) estimated from some previous studies that 6-60\% of children with ADHD continue into adulthood. Therefore, treatment for ADHD is necessary because longitudinal studies showed that attention problems in childhood and adolescence might continue into adulthood (Barkley, 2001).

ADHD is a neurodevelopmental disorder that began to appear in childhood. Based on the Diagnostic and Statistical Manual of Mental Disorders, 5th ed. (DSM-5) ADHD symptom appears and shows impairment before age 12 years (APA, 2013). ADHD can cause behavioral and academic problems. Among the behavioral disorders that can arise from ADHD are CD, ODD, and antisocial behavior (Loeber, Burke, Lahey, Winter, \& Zera, 2000; Mcardle, 2007). Several academic problems commonly faced by ADHD children include having little ability to complete homework (Langberg et al., 2010), low learning achievement (Barry, Lyman, \& Klinger, 2002; Bussing et al., 2012; Molina et al., 2009), and high grade-retention rates (Molina et al., 2009) compared to children in general (not-ADHD).

APA (2013) in DSM-5 stated that genetic and neurological factors that interact with the environment are the causes of ADHD. Biological influence, such as toxins and infections are particularly among the biggest contributors to reasons of this disorder (Barkley, 2014a). ADHD cannot arise only because of social factors such as the way a parent raises a child, family conflicts, insecure attachments, exposure to television or video games, and or interactions with peers. Social factors can only be a risk factor for ADHD when interacting with children who are genetically and neurologically at risk for ADHD (Barkley, 2014a).

Parts of the brain that are impaired and cause decreased executive function are the prefrontal cortex/PFC (Assef, Capovilla, \& Capovilla, 2007; Thompson-schill, Ramscar, \& Chrysikou, 2009). The late development of PFC can have adverse consequences on children's behavior. It also causes the cognitive control that helps children learn to develop less optimally. The executive function is considered to be the factor that most influences the emergence of ADHD symptom in children (Lambek et al., 2011; Mullane, Corkum, Klein, McLaughlin, \& Lawrence, 2011; Sergeant, Geurts, \& Oosterlaan, 2002). In a parallel analysis of executive functions, Miyake et al. (2000) identified three primary functions of executive function, namely shifting, updating, and inhibition. Among these three executive functions, the most contributing to ADHD is inhibition 
(Barkley, 1997; Geurts, Verté, Oosterlaan, Roeyers, \& Sergeant, 2004, 2005; Nigg, 2001; Richardson, 2008; Scheres et.al., 2004; Skillings, 2013).

Inhibition is the process of blocking or preventing a larger, automatic, and dominant response when needed. In the process of inhibition, there is an attempt to avoid or exclude a tendency to respond more dominantly or more automatically. Inhibition correlates perfectly with the executive function in general (Miyake \& Friedman, 2012). According to Miyake et al. (2000), these three executive functions work separately and can be separated. Nigg (2000) stated that inhibition is a range of mechanisms that allow a person to suppress intrusive thoughts and actions or previous activated thoughts or actions, and seek to resist the disturbance of irrelevant stimuli. According to Dempster, the main thing on inhibition control is the ability to suppress the process or excretion of information that would interfere with the completion of the primary goal (as cited in Richardson, 2008, para. 2). The key to this executive function allows for the control of complex cognitions and behaviors and is essential for effective interaction with the environment. Kochanska stated that inhibition control is important in attention, memory, intelligence, as well as related to social competence and emotional regulation (in Richardson, 2008, para. 2). Children with impaired inhibition have difficulty in prioritizing response to tasks related to stimulus (Hughes, Graham, \& Grayson, 2004).

Inhibition has a significant role in a child's life. In a social environment, children with weak inhibition abilities tend to withdraw from social environment (Rubin, Coplan, \& Bowker, 2009; Walker, Henderson, Degnan, Penela, \& Fox, 2015), has a significant risk of developing social anxiety disorder, and not being assertive (Clauss \& Blackford, 2012). In academic terms, children with moderate inhibition abilities tend to find it difficult to focus on learning at home or school. In a study conducted by Bull and Scerif (2001), it was found that children with little inhibition ability and inadequately supported working memory, had lower mathematical abilities than other children of their age. Also, children with low inhibitory ability tend to withdraw from their environment, and it is positively associated with low academic achievement (Chen, Rubin, \& Li, 1997).

Inhibition develops according to the development of the human brain. According to Crone et al., the prefrontal section that affects inhibitory ability develops with age until the person reaches their optimum function in young adulthood (in Crone, Bunge, van der Molen, \& Ridderinkhof, 2006, p. 278). According to Cepeda, Kramer, and Gonzalez de Sather (2001), however, adult performance on executive function has been achieved at age 12. With the growing pre-frontal part that serves to control the various tasks of this executive function, the capacity of one's ability for inhibition and mental flexibility will also increase as the assignments become more varied (Diamond, 2002).

People with ADHD showed poor results on tests that measured inhibitory abilities, such as the Stop-Signal Task, Antisaccade Task (Friedman \& Miyake, 2004), and Color Word Stroop Task (Assef et al., 2007; Ikeda, Okuzumi, \& Kokubun, 2013; López-Villalobos et al., 2010; Thursina et al., 2015). Adams, Milich, and Fillmore (2010) found that children with ADHD had slower inhibition responses than other kids with normal developmental stages. This study is supported by the research conducted by Tye et al. (2014) who found that children with ADHD showed deficits in attention orientation and inhibitory control.

Although many studies support that inhibition is a core-deficit in children with ADHD, there is research that suggests that inhibition is neither a core-deficit nor a differentiating factor between ADHD and non-ADHD children. In a study conducted by Corbett and Constantine (as cited in Weyandt \& Gudmundsdottir, 2014, p. 128), it was found that deficits in inhibition were not only found in ADHD children but also in other clinical groups. However, ADHD children in this study did have weak inhibition ability. Research conducted by Skogli et al. (in Weyandt \& Gudmundsdottir, 2014, p. 128) found that although there was a difference between ADHD and non-ADHD children in executive function, it cannot distinguish between the three subtypes of ADHD.

This study aims to demonstrate that inhibition is a differentiating factor between ADHD and non-ADHD children, and looks at differences in inhibition ability in all three ADHD subtypes in children aged 6 to 12 using the Stroop Color and Word Test. The questions in this study are: (1) Is the inhibition ability in children with 
Rahmi, I., \& Wimbarti, S.

ADHD lower than children without ADHD?; (2) Is there a difference in inhibition ability in the ADHD subtypes of inattentive, hyperactive-impulsive, and combination?; And (3) Is the inhibition ability in children aged 6-9 years lower than children aged 10-12 years?

\section{Methods}

\subsection{Subject}

Subjects in the study were ADHD children $(\mathrm{N}=34)$ consisting of subtypes inattentive $(\mathrm{N}=14)$, hyperactive $(\mathrm{N}=9)$, combination $(\mathrm{N}=11)$, and non-ADHD $(\mathrm{N}=34)$ aged 6- 12 years old. The subjects of ADHD in this study were not comorbid with other disorders. Non-ADHD subjects in this study were subjects who did not experience any psychological disorder (normal) from the diagnosis that has been done by a psychologist. The subject exclusion criteria in this study are: a) Experiencing pervasive developmental disorders or psychosis, b) Experiencing brain trauma with loss of consciousness, c) Having hearing and vision impairments, d) Having an IQ under 80 (WISC) / grade 4 (CPM), this limitation aims to control the existence of a child with intellectual disability, and e) Under medical treatment. Individual differences are controlled by matching the gender, age, and IQ for ADHD and non-ADHD Children.

\subsection{Research Instrument}

Inhibitory ability was measured using Stroop Color and Word Test (SCWT) for children (Golden, Freshwater, \& Golden, 2003), which measure inhibitory responses in children aged 5-14 years. SCWT is an executive function measurement tool that was originally developed to measure selective attention and cognitive flexibility. SCWTconsists of three parts, each of which consists of 100 items presented in 5 columns. The first part is a word page composed of the word "RED," "GREEN," and "BLUE" which were randomly arranged and presented in black. The second part is a color page (color task) consisting of the word "XXXX" which is shown in red, green, and blue ink at random. The third part is a color-word task, which consists of the words "RED," "GREEN," and "BLUE" which were arranged randomly and presented in colors that do not match the color of the written word (the word "RED" printed in blue). This third part (Color-Word task) is a component that can measure mental flexibility and ability to withstand more dominant responses/inhibitions (Wecker, Kramer, Wisniewski, Delis, \& Kaplan, 2000).

SCWT is presented for 45 seconds for each section and can be administrated individually or in groups. The reliability of the Stroop test scores has a very high consistency across all test versions. Reliability analysis is done by the test-retest method with a time span of one minute to 10 days. This test has a good reliability with the reliability coefficient of word page 0.89 , color page 0.84 , and color-word page 0.73 for administration in groups, and the word page 0.86 , color page 0.82 , and color- word page 0.73 for single administration (Golden et al., 2003). Stroop Test has a good validity in measuring inhibition. The interference score is well correlated with other tests that measured pre-potent response in inhibitions such as the possibility of stopping $(r=0.33)$ and time ( $\mathrm{r}=0.56)$ in Stop-Signal Task (Friedman \& Miyake, 2004; May \& Hasher as cited in Strauss, Sherman, \& Spreen, 2006) and the difference in scores between Trails A and B (May \& Hasher as cited in Strauss et al., 2006).

\subsection{Data Analysis}

The data analysis was done using variance analysis to find the differences in inhibition ability of children with different ADHD status (ADHD and non-ADHD) and age ranges (6-9 years and 10-12 years of age) and the interaction between the two; the researchers used two-way variance analysis / two-way ANOVA. Meanwhile, to explore the ability of inhibition between inattentive, hyperactive, and combination ADHD subtypes, the researcher used one-way variance / one-way ANOVA. 


\section{Results}

\subsection{Interference Score Overview}

Interference score describes the ability of one's inhibition. The interference score is inversely proportional to one's inhibition ability. The higher a person's interference score, the worse the inhibition ability will be and vice versa. The description of subject interference scores in this study can be seen in table 1 . The mean of the subjects' interference score in this study was 51.132 from the range of scores of 20-80 indicating a high interference number. Golden et al. (2003) stated that the higher interference score with the color page and normal page score shows the presence of prefrontal disorder especially when the T-score is above 60 .

\section{Table 1}

T-score of subject interference

\begin{tabular}{llcccc}
\hline \multicolumn{1}{c}{ Category } & Variant & $\begin{array}{c}\text { Minimum } \\
\text { Score }\end{array}$ & $\begin{array}{c}\text { Maximum } \\
\text { Score }\end{array}$ & Mean & $\begin{array}{c}\text { Number of children } \\
\text { with scores }>60\end{array}$ \\
\hline Disorder Status & ADHD & 41 & 78 & 54.191 & 11 \\
& Non-ADHD & 27 & 61 & 48.989 & 2 \\
Age group & 6-9 years & 34 & 68 & 52.444 & 10 \\
& 10-12 years & 27 & 78 & 48.736 & 3 \\
All Subjects & & 27 & 78 & 51.132 & 13 \\
\hline
\end{tabular}

Note. The scores in this table are the interference scores that have been converted to T-Score based on the raw score conversion table to the T-Score on the Stroop Test Manual (Golden et al., 2003).The interference score range is (minus) 50-37 for the raw score, and 20-80 for the T-score.

\subsection{Findings}

Data analysis was performed by using a two-way variance analysis to determine differences in interference scores between ADHD and non-ADHD children, between children with age group 6-9 years with age group 10-12 years, and the interaction between the disorder status and age group. Based on the two-way ANOVA test, a significant difference in interference score between ADHD and non-ADHD children $(\mathrm{F}=11.810 ; p=.001)$ was found, with children with ADHD having a higher interference score than children with non-ADHD. This result suggests that the inhibition ability of non-ADHD children is better than that of ADHD children.

Also, there were significant differences in interference scores between children within the age group of 6-9 years and $10-12$ years $(\mathrm{F}=3.129 ; p=.041)$. Interference scores of children aged $6-9$ years are higher than those in the latter age group. This score suggests that children aged 10-12 year have better inhibition skills than children in the 6-9-year age group. Furthermore, the researchers looked at the interaction between ADHD disorder status and age group against interference score. Based on the two-way ANOVA test, there was no interaction between ADHD disorder status and age group on interference score $(\mathrm{F}=3.235 ; p=.077)$. In conclusion, there is no interaction between the diagnosis of ADHD and age group in affecting the ability of one's inhibition.

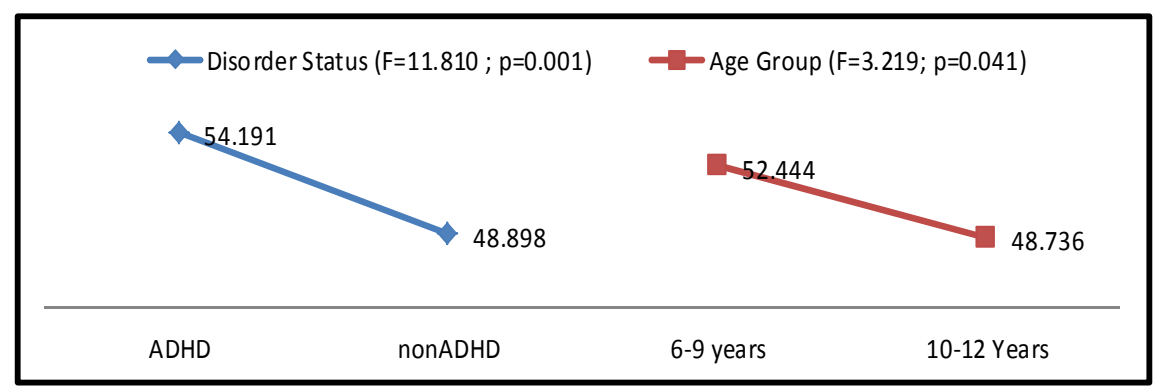

Note. The score in this image is the interference score that has been converted to T-Score based on raw score conversion table to T-Score on Stroop Test Manual (Golden et al., 2003).

Figure 1. Difference test result of subject interference score with different disorder status and age group 
Rahmi, I., \& Wimbarti, S.

To determine the difference in interference score between ADHD children with different subtypes, the researchers used the one-way ANOVA test. One-way ANOVA test results found no significant difference between interference scores in ADHD children with different subtypes $(\mathrm{F}=0.398 ; p=.675)$. This result demonstrates that the inhibition ability of ADHD children with inattentive, hyperactive, and combination subtypes are the same.

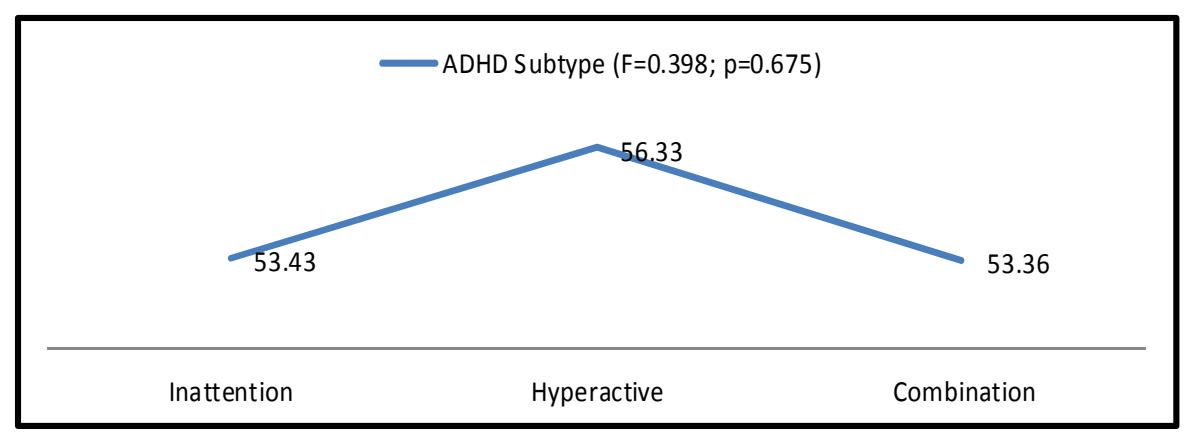

Note. The score in this image is the interference score that has been converted to T-Score based on raw score conversion table to T-Score on the Stroop Test Manual (Golden et al., 2003).

Figure 2. Difference test results of subject interference scores with different ADHD subtypes

As an additional analysis, researchers also saw if there is a relationship between intelligence and the interference score on ADHD children. The correlation of test results has been done; there was no significant association between IQ score with the interference score on ADHD Children $(\mathrm{r}=-0.99 ; p=.578)$. Thus, the ability of one's inhibition is not related to his or her intellectual ability.

\section{Discussions}

The inhibition ability is referred to as the main executive function that experience deficit and dysfunction in children ADHD (Barkley, 1997). Malfunctions in this executive function would create the deficit in other executive functions. Barkley (1997) developed a model that predicts that children with ADHD will experience deficit in three forms of inhibition, namely: (1) inhibition of existing response, like the response that is or has been associated with previous reinforcement, (2) inhibition of the ongoing response, which creates the existence of any delay in deciding to continue a particular response, and (3) the interference control, protecting a response from another response. The results of this study support the above statement that there is a difference in inhibition ability between children with ADHD and non-ADHD children, in which ADHD children have a lower inhibition ability than non-ADHD children.

The findings of this research are also in line with the research conducted by Assef et al. (2007) who found that children with ADHD showed longer reaction time in working on the Stroop Test compared to children without ADHD. This reinforces the hypothesis that children with ADHD show a decrease in inhibitory ability. Also, in a study conducted by Berlin, Bohlin, Nyberg, and Janols (2004) it was found that children with ADHD had significant differences with control groups regarding inhibitory and other executive functional abilities. Response inhibition was placed as key features of ADHD (Barkley, 2014b) reflecting the inherent tendency to 'act without thinking',

In this study, it was found that there is a difference of inhibition between children within the 6-9-year age group compared to those in the 10-12-year age group, which indicates that inhibition ability evolves with increasing age. This result is in line with Crone et al., (as cited in Crone et al., 2006, p. 278) who said that inhibition evolves by the development of the human brain. According to Cepeda, Kramer, and Gonzalez de Sather (2001), adults' executive functions' performance is achieved at the age of 12 years, but Diamond (2013) stated that inhibition ability on executive functioning continues to evolve and mature during adolescence. In a study conducted by Davidson, Amso, Anderson, and Diamond (2006) it was found that inhibition ability increases with age. Inhibition is complex and depends on several other cognitive processes that may rely on 
different neural mechanisms (Cepeda et al., 2001). Therefore, different mechanisms may affect the ability of inhibition in both ADHD and non-ADHD children at various ages.

Inhibition has a relation with the functions of working memory. Both roles support each other in performing its duties (Diamond, 2013). With increasing age, the control over inhibition will be better which is characterized by better accuracy in responding and the decline of impulsivity. Children with older age are increasingly aware of what information they need in the face of a task, helping them to distinguish which information is relevant. This ability helps children to control and restrain irrelevant response from being performed.

The development of inhibition ability is influenced by the development of the Prefrontal Cortex (PFC). The system in the PFC enables people to focus on information stored in the memory and to follow stimulus from the environment selectively. PFC is a part of the brain that takes more time than other areas of the brain in its development. It takes more than two decades to achieve the maturity of the PFC in humans (Fuster, 2002). Diverse research has shown the fact that the length of the PFC development, made PFC sensitive to environmental influences, not only during infancy and prenatal, but also in the time of children and adolescents (Andersen \& Teicher, 2008; Crews, He, \& Hodge, 2007). Therefore, although ADHD is a neurodevelopmental disorder that is affected by nature in the form of being genetically inherited from parents, the progression of the symptoms is more likely influenced by nurture/environment because its development takes a long time and is sensitive to the environment.

In the process, every humans' neurological system has a delicate period in which the nervous system would be most susceptible to environmental influences during that time (Nelson \& Sheridan, 2011; Rice \& Barone, 2000). Any development of the nervous system depends on the exposure to a normal environment that supports its development. This sensitive period is found in the first years of life. However sensitive periods in the development of executive functions that depend on the PFC are at the later age of children because PFC has a slow growth. Same as PFC, ADHD symptoms which are a neurodevelopmental dysfunction, will only appear when interacting with the supportive environment (APA, 2013).

From the results of this research, it is advisable that the increase of age will also reflect individual growth in inhibition. This result contrasts with the case of ADHD children, who experience barriers/dysfunction in the development of the capabilities of his/her inhibition. Shaw et al. (2007) stated that the brain of a child with ADHD matures about three years behind other kids the same age as him/her. The delay in inhibition development is potentially caused by environmental factors that affect the development of executive functions such as the existence of economic difficulties, a caregiver who was rude and uncaring, domestic or community violence, disorganized environment, and the difficulty of accessing nutritious food (Raizada, Mackey, \& Bunge, 2012). Therefore, it takes a positive and supportive environment for the growth of a child's executive functions. A child with a pre-existing genetic condition of a neurological disorder on his/her prefrontal cortex will be more easily influenced by the environment, particularly if the environment is not supportive, such as having many disruptions or inadequate parenting.

The differences in the development patterns of executive function, particularly on inhibition among ADHD and non-ADHD children, requires the groups to receive different environmental treatments improve their respective roles. ADHD children with disrupted executive function require intensive environmental intervention for it to operate properly (Mackey et al., 2012). If a child with ADHD does not receive an intervention, then his/her inhibition ability will worsen, and it can affect their lives in the future.

Based on Center on the Developing Child at Harvard University (2014) adults can facilitate the development of executive functions of a child by modeling social behavior regularly, and create and maintain relationships that are supportive and reliable. Children's programming can also train their development skills by doing activities that foster creative games and social relationships, teach children how to deal with stress, involve continuous practice to provide more opportunities for children and reduce the supervision of adults. The most important environmental factor for the development of executive function is the fact that children learn these 
Rahmi, I., \& Wimbarti, S.

skills through experience, cumulatively with continuous improvement.

In this study, we found no difference in inhibition between all three ADHD subtypes. This result contrasts with previous research by Jiménez, Ballabriga, Martin, Arrufat, and Giacobo (2015) who found that low inhibition and initiative are unique to ADHD Children within the inattentive subtype. However, the results of this study are consistent with research conducted by Adams et al. (2010) who discovered that there is a difference between the inhibition ability of ADHD and non-ADHD children, but no difference in inhibition ability was found among different subtypes of ADHD children. The existence of similar inhibition between three subtypes of ADHD requires further consideration because these three subtypes have differences in cognitive function and behavior (Diamond, 2005). The existence of similar interference score between inattentive ADHD which is the inhibition disorders with ADHD hyperactivity and combinations can be caused due to the subtype of the third share 'core deficit'. The presence of similar inhibitory abilities between these three subtypes of ADHD further reinforces that low inhibitory ability is a central feature of ADHD.

In the additional analysis of this study, researchers also found that there is no association between a person's inhibition and intellectual ability. Although several studies mentioned that the capacity of inhibition has a strong correlation with the fluid intelligence in adults (Polderman et al., 2009). Salthouse, Atkinson, and Berish (2003) found that the correlation between intelligence and inhibition occurs only at the age of 9, 12, and 18 years old. A study conducted by Duan et al. (2009) found that children with above average intellectual level have better performance than a child with average intelligence level in the go/no go gauge response inhibition task. The results of this study are in line with research done by (Duan \& Shi, 2011) who found that intelligence and inhibition are not correlated with any age. In a study conducted by Friedman et al. (2006) that tests correlation between the fluid and crystallized intelligence, and the third with WISC executive functions separately, found that working memory is associated with intelligence, while inhibition and shifting are not related. Note that the data in this study is limited to the sample aged 6-12 years. Therefore, the absence of a relationship between intelligence and inhibition in this research cannot be generalized to all ages.

\section{Conclusions and Suggestions}

Based on the results of the present research, the conclusions to be drawn are as followed: 1) the inhibition ability in ADHD children is lower than non-ADHD children. Most children with ADHD score higher interference than non-ADHD children. This result means that ADHD children have difficulty in holding a larger response and are unable to control irrelevant response from the performed task. 2) The inhibition ability in children ages 6-9 years are lower than children ages 10-12 years. This result means that inhibition evolves with age; with the increasing age a child will be better able to control their response to an irrelevant stimulus. 3) There is no difference in inhibition among children with different ADHD subtypes namely, inattentive, hyperactive/impulsive, and combination. Inhibition among these three ADHD subtypes is relatively the same which suggests that low inhibition is indeed a main characteristic of ADHD.

ADHD children have lower inhibition than non-ADHD children, they have difficulties in preventing a more automatic and larger response when needed. Therefore, parents and teachers who deal with ADHD children should limit distraction from children's environment. For example television, video games, and computer. Electronic devices are a great distractor for children and encourage impulsive behavior. Teachers and parents can decrease children's time with electronic devices and increase children's time doing activities outdoor. Parents and teachers can also create a special, quiet, and organized place for children to do homework, read, and take a rest. It also can reduce distraction because, in neat and organized place, children know where everything goes.

There are still limitations in this research, which is that it is still limited to the inhibition in ADHD and non-ADHD children's executive functions. Therefore, the researchers suggest that future research explore all components of executive functions to create a more comprehensive result in obtaining a more accurate early detection and intervention system in ADHD children. 


\section{References}

Adams, Z. W., Milich, R., \& Fillmore, M. T. (2010). Examining manual and visual response inhibition among ADHD subtypes. Journal of Abnormal Child Psychology, 38(7), 971-983. https://doi.org/10.1007/s10802-010-9420-3

American Psychiatric Association. (2013). Diagnostic and Statistical Manual of Mental Disorders (DSM-5) (5th Ed.). Washington, DC: American Psychiatric Association. https://doi.org/10.1176/appi.books.9780890425596.744053

Andersen, S. L., \& Teicher, M. H. (2008). Stress, sensitive periods and maturational events in adolescent depression. Trends in Neurosciences, 31, 183-191. https://doi.org/10.1016/j.tins.2008.01.004

Assef, E. C., Capovilla, A. G., \& Capovilla, F. C. (2007). Computerized Stroop test to assess selective attention in children with attention deficit hyperactivity disorder. The Spanish Journal of Psychology, 10(1), 33-40. https://doi.org/10.1017/S1138741600006296

Barbaresi, W. J., Weaver, A. L., Voigt, R. G., Killian, J. M., \& Katusic, S. K. (2015). Comparing methods to determine persistence of childhood ADHD into adulthood: A prospective, population-based study. Journal of Attention Disorders, 1-10. https://doi.org/10.1177/1087054715618791

Barkley, R. A. (1997). Behavioral inhibition, sustained attention, and executive functions: Constructing a unifying theory of ADHD. Psychological Bulletin, 121(c), 65-94. https://doi.org/10.1037/0033-2909.121.1.65

Barkley, R. A. (2001). The executive functions and self-regulation: An evolutionary neuropsychological perspective. Neuropsychology Review, 11(1), 1-29. https://doi.org/10.1023/A:1009085417776

Barkley, R. A. (2014a). Etiologies of ADHD. In R. A. Barkley (Ed.), Attention-Deficit Hyperactivity Disorder: A handbook for diagnosis and treatment (4th ed., pp. 356-390). New York: The Guilford Press.

Barkley, R. A. (2014b). Executive functioning and self-regulation viewed as an extended phenotype: Implications of the theory for ADHD and its treatment. In R. A. Barkley (Ed.), Attention-Deficit Hyperactivity Disorder: A handbook for diagnosis and treatment (4th ed., pp. 405-434). New York: Guilford Press.

Barry, T. D., Lyman, R. D., \& Klinger, L. G. (2002). Academic underachievement and Attention-Deficit / Hyperactivity Disorder: The negative impact of symptom severity on school performance. Journal of School Psychology, 40(3), 259-283. https://doi.org/10.1016/S0022-4405(02)00100-0

Berlin, L., Bohlin, G., Nyberg, L., \& Janols, L. (2004). How well do measures of inhibition and other executive functions discriminate between children with ADHD and controls? Child Neuropsychology, 10(1), 1-13. https://doi.org/10.1076/chin.10.1.1.26243

Bull, R., \& Scerif, G. (2001). Executive functioning as a predictor of children's mathematics ability: Inhibition, switching, and working memory. Developmental Neuropsychology, 19(3), 273-293. https://doi.org/10.1207/S15326942DN1903

Bussing, R., Porter, P., Zima, B. T., Mason, D., Garvan, C., \& Reid, R. (2012). Academic outcome trajectories of students with ADHD: Does exceptional education status matter? Journal of Emotional and Behavioral Disorders, 20(3), 131-143. https://doi.org/10.1177/1063426610388180

Center on the Developing Child at Harvard University. (2014). Enhancing and practicing executive function skills with children from infancy to adolescence. Retrieved from https://www.developingchild.harvard.edu

Cepeda, N. J., Kramer, A. F., \& Gonzalez de Sather, J. C. M. (2001). Changes in executive control across the life span: Examination of task-switching performance. Developmental Psychology, 37(5), 715-730. https://doi.org/10.1037/0012-1649.37.5.715

Chen, X., Rubin, K. H., \& Li, D. (1997). Relation between academic achievement and social adjustment: Evidence from Chinese children. Developmental Psychology, 33(3), 518-525. https://doi.org/10.1037/0012-1649.33.3.518

Christina, Y. M. (2012). Comparison of risk factors for attention / hyperactivity disorder in children in rural and urban areas in Kecamatan Cangkringan Sleman district [Perbandingan faktor risiko gangguan 
Rahmi, I., \& Wimbarti, S.

pemusatan perhatian/hiperaktivitas pada anak di daerah pedesaan dan perkotaan di kecamatan cangkringan kabupaten sleman] (Unpublished thesis). Universitas Gadjah Mada, Yogyakarta.

Clauss, J., \& Blackford, J. (2012). Behavioral inhibition and risk for developing social anxiety disorder: A meta-analytic study. Journal of the American Academy of Child and Adolescent Psychiatry, 51(10), 1-13. https://doi.org/10.1016/j.jaac.2012.08.002

Crews, F., He, J., \& Hodge, C. (2007). Adolescent cortical development: A critical period of vulnerability for addiction. Pharmacology Biochemistry and Behavior, 86, 189-199. https://doi.org/10.1016/j.pbb.2006.12.001

Crone, E. A., Bunge, S. A., van der Molen, M. W., \& Ridderinkhof, K. R. (2006). Switching between tasks and responses: A developmental study. Developmental Science, 9(3), 278-287. https://doi.org/10.1111/j.1467-7687.2006.00490.x

Davidson, M. C., Amso, D., Anderson, L. C., \& Diamond, A. (2006). Development of cognitive control and executive functions from 4 to 13 years: Evidence from manipulations of memory, inhibition, and task switching. Neuropsychologia, 44(11), 2037-2078. https://doi.org/10.1016/j.neuropsychologia.2006.02.006

Dewi, M. S. (2011). The role of cigarette smoke when pregnant women as risk factors distraction concentration attention/hyperactive primary school children in Kecamatan Banguntapan Bantul District Daerah Istimewa Yogyakarta [Peranan Asap Rokok Saat Ibu Hamil Sebagai Faktor Risiko Gangguan Pemusatan Perhatian/hiperaktivitas Anak Sekolah Dasar Di Kecamatan Banguntapan Kabupaten Bantul Daerah Istimewa Yogyakarta] (Unpublished thesis). Universitas Gadjah Mada, Yogyakarta.

Diamond, A. (2002). Normal development of prefrontal cortex from birth to young adulthood: cognitive functions, anatomy, and biochemistry. In D. T. Stuss \& R. T. Knight (Eds.), Principles of frontal lobe function (pp. 466-503). London: Oxford University Press. https://doi.org/10.1093/acprof:oso/9780195134971.003.0029

Diamond, A. (2005). Attention-deficit disorder (attention-deficit/ hyperactivity disorder without hyperactivity): a neurobiologically and behaviorally distinct disorder from attention-deficit/hyperactivity disorder (with hyperactivity). Development and Psychopathologythology, 17, 807-825. https://doi.org/10.1017/S0954579405050388

Diamond, A. (2013). Executive functions. Annual Review of Psychology, 64, 135-68. https://doi.org/10.1146/annurev-psych-113011-143750

Duan, X., \& Shi, J. (2011). Intelligence does not correlate with inhibitory ability at every age. Procedia - Social and Behavioral Sciences, 12, 3-8. https://doi.org/10.1016/j.sbspro.2011.02.003

Duan, X., Shi, J., Wu, J., Mou, Y., Cui, H., \& Wang, G. (2009). Electrophysiological correlates for response inhibition in intellectually gifted children: A go/nogo study. Neuroscience Letters, 457(1), 45-48. https://doi.org/10.1016/j.neulet.2009.04.006

Friedman, N. P., \& Miyake, A. (2004). The relations among inhibition and interference control functions: a latent-variable analysis. Journal of Experimental Psychology: General, 133(1), 101-135. https://doi.org/10.1037/0096-3445.133.1.101

Friedman, N. P., Miyake, A., Corley, R. P., Young, S. E., DeFries, J. C., \& Hewitt, J. K. (2006). Not all executive functions are related to intelligence. Psychological Science, 17(2), 172-9. https://doi.org/10.1111/j.1467-9280.2006.01681.x

Fuster, J. M. (2002). Frontal lobe and cognitive development. Journal of Neurocytology, 31, 373-385. https://doi.org/10.1023/A:1024190429920

Geurts, H. M., Verté, S., Oosterlaan, J., Roeyers, H., \& Sergeant, J. A. (2004). How specific are executive functioning deficits in attention deficit hyperactivity disorders and autism? Journal of Child Psychology and Psychiatry and Allied Disciplines, 45(4), 836-854. https://doi.org/10.1111/j.1469-7610.2004.00276.x

Geurts, H. M., Verté, S., Oosterlaan, J., Roeyers, H., \& Sergeant, J. A. (2005). ADHD subtypes: Do they differ in their executive functioning profile? Archives of Clinical Neuropsychology, 20(4), 457-477. https://doi.org/10.1016/j.acn.2004.11.001 
Golden, C. J., Freshwater, S. M., \& Golden, Z. (2003). Stroop colour and word test children's version for ages 5-14: A manual for clinical and experimental uses. Illinois: Stoelting Co.

Guldberg-Kjär, T., \& Johansson, B. (2015). ADHD symptoms across the lifespan: a comparison of symptoms captured by the Wender and Barkley Scales and DSM-IV criteria in a population-based Swedish sample aged 65 to 80. Journal of Attention Disorders, 19(5), 390-404. https://doi.org/10.1177/1087054713514853

Hayati, L. (2014). Watching television and playing video games as a risk factor interference central concentration/hyperactivity in children [Menonton Televisi Dan Bermain Video Games Sebagai Faktor Risiko Ganggguan Pemusatan Perhatian/Hiperaktivitas Pada Anak] (Unpublished thesis). Universitas Gadjah Mada, Yogyakarta.

Hughes, C., Graham, A., \& Grayson, A. (2004). Executive function in childhood: Development and disorder. In J. Oates \& A. Grayson (Eds.), Cognitive and language development in children (pp. 205-232). Oxford, UK: Blackwell Publishing Ltd.

Ikeda, Y., Okuzumi, H., \& Kokubun, M. (2013). Stroop/reverse-Stroop interference in typical development and its relation to symptoms of ADHD. Research in Developmental Disabilities, 34(8), 2391-2398. https://doi.org/10.1016/j.ridd.2013.04.019

Jiménez, E. A. A., Ballabriga, M. C. J., Martin, A. B., Arrufat, F. J., \& Giacobo, R. S. (2015). Executive functioning in children and adolescents with symptoms of sluggish cognitive tempo and ADHD. Journal of Attention Disorders, 19(6), 507-514. http://doi.org/10.1177/1087054713495442

Lambek, R., Tannock, R., Dalsgaard, S., Trillingsgaard, A., Damm, D., \& Thomsen, P. H. (2011). Executive dysfunction in school-age children with ADHD. Journal of Attention Disorders, 15(8), 646-655. http://doi.org/10.1177/1087054710370935

Langberg, J. M., Arnold, L. E., Flowers, A. M., Jeffery N, E., Altaye, M., Hinshaw, S. P., Hectman, L. (2010). Parent-report homework problems in the MTA study: Evidence for sustained improvement with behavioral treatment. Journal of Clinical Child \& Adolescent Psychology, 39(2), 220-233. https://doi.org/10.1080/15374410903532700

Loeber, R., Burke, J. D., Lahey, B. B., Winters, A., \& Zera, M. (2000). Oppositional defiant and conduct disorder: A review of the past 10 years, Part I. Journal of the American Academy of Child \& Adolescent Psychiatry, 39(12), 1468-1484. https://doi.org/10.1097/00004583-200012000-00007

López-Villalobos, J. A., Serrano-Pintado, I., Andrés-De Llano, J. M., Sánchez-Mateos, J. D., Alberola-López, S., \& Sánchez-Azón, M. I. (2010). Usefulness of the Stroop test in attention deficit hyperactivity disorder. Revista de Neurologia, 50(6), 334-340.

Mackey, A. P., Raizada, R. D., \& Bunge, S. A. (2012). Environmental influences on prefrontal development. In D. T. Stuss \& R. T. Knight (Eds.), Principles of frontal lobe function (2nd ed., pp. 145-163). London: Oxford University Press.

Mcardle, P. (2007). ADHD and comorbid oppositional defiant and conduct disorders. In M. Fitzgerald, M. Bellgrove, \& M. Gill (Eds.), Handbook of attention deficit hyperactivity disorder (pp. 53-68). West Sussex: John Wiley \& Sons, Ltd.

Miyake, A., \& Friedman, N. P. (2012). The nature and organization of individual differences in executive functions: Four general conclusions. Current Directions in Psychological Science, 21(1), 8-14. https://doi.org/10.1177/0963721411429458

Miyake, A., Friedman, N. P., Emerson, M. J., Witzki, A. H., Howerter, A., \& Wager, T. D. (2000). The unity and diversity of executive functions and their contributions to complex "Frontal Lobe" tasks: A latent variable analysis. Cognitive Psychology, 41, 49-100. https://doi.org/10.1006/cogp.1999.0734

Molina, B. S. G., Hinshaw, S. P., Swanson, J. M., Arnold, L. E., Vitiello, B., Jensen, P., ... MTA Cooperative Group. (2009). The MTA at 8 years: Prospective follow-up of children treated for combined type ADHD in a multisite study. Journal of the American Academy of Child \& Adolescent Psychiatry, 48(5), 484-500. https://doi.org/10.1097/CHI.0b013e31819c23d0

Mullane, J. C., Corkum, P. V, Klein, R. M., McLaughlin, E. N., \& Lawrence, M. a. (2011). Alerting, orienting, and executive attention in children with ADHD. Journal of Attention Disorders, 15(4), 310-320. 
Rahmi, I., \& Wimbarti, S.

http://doi.org/10.1177/1087054710366384

National Institute of Mental Health. (2009). National survey tracks rates of common mental disorders among american youth. Retrieved from

http://www.nimh.nih.gov/news/science-news/2009/national-survey-tracks-rates-of-common-mental-dis orders-among-american-youth.shtml

Nelson, C., \& Sheridan, M. (2011). Lessons from neuroscience research for understanding causal links between family and neighborhood characteristics and educational outcomes. In G. J. Duncan \& R. J. Murnane (Eds.), Whither opportunity: Rising inequality, schools, and children's life chances (pp. 27-46). New York, NY: Russell Sage Foundation.

Nigg, J. T. (2000). On inhibition/disinhibition in developmental psychopathology: Views from cognitive and personality psychology and a working inhibition taxonomy. Psychological Bulletin, 126(2), 220-246. https://doi.org/10.1037/0033-2909.126.2.220

Nigg, J. T. (2001). Is ADHD a disinhibitory disorder? Psychological Bulletin, 127(5), 571-598. https://doi.org/10.1037/0033-2909.127.5.571

Polderman, T. J. C., de Geus, E. J. C., Hoekstra, R. A., Bartels, M., van Leeuwen, M., \& Verhulst, F. C. (2009). Attention problems, inhibitory control and intelligence index overlapping genetic factors: a study in 9 , 12 and 18-year-old twins. Neuropsychology, 23(3), 381-391. https://doi.org/10.1037/a0014915

Rice, D., \& Barone, S. J. (2000). Critical periods of vulnerability for the developing nervous system: Evidence from humans and animal models. Environmental Health Perspectives, 108(Suppl 3), 511-533. https://doi.org/10.1289/ehp.00108s3511

Richardson, T. H. (2008). Inhibitory control in psychiatric disorders: A review of neuropsychological and neuroimaging research. Undergraduate Research Journal for the Human Sciences, 7. Retrieved from https://www.kon.org/urc/urc research_journal7.html

Roberts, W., Milich, R., \& Barkley, R. A. (2014). Primary Symptoms, Diagnostic Criteria, Subtyping, and Prevalence of ADHD. In R. A. Barkley (Ed.), Attention-Deficit Hyperactivity Disorder: A handbook for diagnosis and treatment (4th ed., pp. 51-80). New York: The Guilford Press.

Rubin, K. H., Coplan, R. J., \& Bowker, J. C. (2009). Social withdrawal in childhood. Annual Review of Psychology, 60, 141-171. https://doi.org/10.1146/annurev.psych.60.110707.163642.Social

Salthouse, T. A., Atkinson, T. M., \& Berish, D. E. (2003). Executive functioning as a potential mediator of agerelated cognitive decline in normal adults. Journal of Experimental Psychology: General, 132(4), 566-594. https://doi.org/10.1037/0096-3445.132.4.566

Saputro, D. (2004). Hyperkinetic disorders in children in DKI Jakarta: New diagnosis instrument formation, prevalence determination, pathophysiological research, and therapeutic efforts [Gangguan Hiperkinetik pada Anak di DKI Jakarta: Penyusunan Instrumen Diagnosis Baru, Penentuan Prevalensi, Penelitian Patofisiologis, dan Upaya Terapi] (Unpublished doctoral dissertation). Universitas Gadjah Mada, Yogyakarta.

Scheres, A., Oosterlaan, J., Geurts, H., Morein-Zamir, S., Meiran, N., Schut, H., Sergeant, J. A. (2004). Executive functioning in boys with ADHD: Primarily an inhibition deficit? Archives of Clinical Neuropsychology, 19(4), 569-594. http://doi.org/10.1016/j.acn.2003.08.005

Sergeant, J. A., Geurts, H., \& Oosterlaan, J. (2002). How specific is a deficit of executive functioning for attention-deficit/hyperactivity disorder? Behavioural Brain Research, 130(1-2), 3-28. https://doi.org/10.1016/S0166-4328(01)00430-2

Shaw, P., Eckstrand, K., Sharp, W., Blumenthal, J., Lerch, J. P., Greenstein, D., Rapoport, J. L. (2007). Attention-deficit/hyperactivity disorder is characterized by a delay in cortical maturation. Proceedings of the National Academy of Sciences of the United States of America, 104(49), 19649-19654. https://doi.org/10.1073/pnas.0707741104

Skillings, L. M. (2013). Advance day by day with encouragement, accountability, support and empowerment. Retrieved from http://addwithease.com/what-the-ef-executive-functions-response-inhibition

Strauss, E., Sherman, E. M. S., \& Spreen, O. (2006). A compendium of neuropsychological tests: Administration, norms, and commentary (3rd ed.). New York: Oxford University Press. 
Thompson-schill, S. L., Ramscar, M., \& Chrysikou, E. G. (2009). When a little frontal lobe goes a long way. Current Directions in Psychological Science, 18(5), 259-263. https://doi.org/10.1111/j.1467-8721.2009.01648.x

Thursina, C., Ar-Rochmah, M., Nurputra, D. K., Harahap, I. S. K., Harahap, N. I. F., Sa'Adah, N., Kitayama, S. (2015). Attention Deficit/Hyperactivity Disorder (ADHD): Age related change of completion time and error rates of Stroop Test. The Kobe Journal of Medical Sciences, 61(1), 19-26.

Tye, C., Asherson, P., Ashwood, K. L., Azadi, B., Bolton, P., \& Mcloughlin, G. (2014). Attention and inhibition in children with ASD, ADHD and comorbid ASD + ADHD: An event-related potential study. Psychological Medicine, 44, 1101-1116. https://doi.org/10.1017/S0033291713001049

Walker, O. L., Henderson, H. A., Degnan, K. A., Penela, E. C., \& Fox, N. A. (2015). Associations between behavioral inhibition and children's social problem solving behavior during social exclusion. Social Development, 23(3), 487-501. https://doi.org/10.1111/sode.12053

Wecker, N. S., Kramer, J. H., Wisniewski, A., Delis, D. C., \& Kaplan, E. (2000). Age effects on executive ability. Neuropsychology, 14(3), 409-414. https://doi.org/10.1037/0894-4105.14.3.409

Weyandt, L. L., \& Gudmundsdottir, B. G. (2014). Developmental and neuropsychological deficits in children with ADHD. In R. A. Barkley (Ed.), Attention-Deficit Hyperactivity Disorder: A handbook for diagnosis and treatment (4th ed., pp. 116-139). New York: The Guilford Press.

Wimbarti, S., Dewi, A. A. A., \& Khoirot, U. (2016). Adaptation of Conners teacher rating scale in children aged 6-12 years and its use is associated with attribution and aggressive behavior of ADHD children [Adaptasi conners teacher rating scale pada anak usia 6-12 tahun dan penggunaannya dikaitkan dengan atribusi dan perilaku agresif anak ADHD] (Unpublished research report). Universitas Gadjah Mada, Yogyakarta. 
Rahmi, I., \& Wimbarti, S. 